\title{
FOLLOW-UP USAGE OF THE SCOTT-CRAIG ORTHOSIS IN PARAPLEGIA
}

\author{
By William E. O’Daniel, ${ }^{1}$ Jr., B.S., R.P.T. and Harry R. Hahn, ${ }^{2}$ M.D. \\ ${ }^{1}$ Director, Physical Therapy Department, ${ }^{2}$ Medical Director, Director of Research and \\ Education, Craig Hospital, 3425 South Clarkson, Englewood, Colorado 801 Io, U.S.A.
}

\begin{abstract}
A survey of the usage of the Scott-Craig Orthosis among individuals with LI or above complete motor and sensory paraplegia is reported. Patients were grouped according to those without volitionally controlled abdominal musculature (C8-T5), those with volitionally controlled upper abdominal musculature (T6-T9), and those with all abdominal musculature under volitional control (TIO-LI). The study was done in two phases. Phase I, done in I976, consisted of a survey of I84 patients in this neurological grouping who received the Scott-Craig Orthosis at Craig Hospital from I January 1964 through to 3I December I975. Phase II was completed in December I980. Sixty-three additional patients were surveyed who were braced from I January I976 through to 3I December 1979. Long-term usage and some form of ambulation was found in 77 per cent of those surveyed.
\end{abstract}

Key words: Paraplegia; Orthosis (Scott-Craig); Leg bracing.

\section{Purpose}

THE survey was conducted in order that long-term usage of the Scott-Craig Orthosis could be defined for those patients with an $\mathrm{L}_{\mathrm{I}}$ or above complete motor and sensory paraplegia. Neurological level is defined as the lowest functional normal nerve root present. The authors also feel it would be important to know the reason patients used or did not use their orthoses.

\section{Population}

The surveys were done in December I976 and December I980 at Craig Hospital. An attempt was made to contact all individuals with complete motor and sensory level paraplegia at $\mathrm{L}_{\mathrm{I}}$ or above who received the Scott-Craig Orthosis as an inpatient during the period I January I964 through to 3I December 1979. There were 445 patients (4I per cent) out of a total of 1094 in this neurological grouping who received the Scott-Craig Orthosis. Involved in this group were seven individuals with neurological lesions at the C8 level who received the orthosis. Two hundred and forty-seven patients ( 56 per cent of the total braced during the survey period) were contacted. The remaining 44 per cent were no longer living at the address available to us. Eighty-nine per cent had been braced two years or longer in Phase I, 68 per cent over two years in Phase II.

\section{Survey of Literature}

Stauffer and associates (1978) felt the most efficient type of bracing for the patient at TI-TII levels would be posterior splints for standing purposes. Hahn (1970) reported 86 per cent of those individuals with LI or above complete lesions 
used orthoses. Rosman and Spira (1974) reviewed the literature. They also reported a survey showing that individuals at $\mathrm{TI}-\mathrm{T} 6$ levels did not use orthoses at

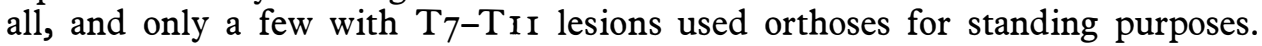
Coghlan et al. (1980) reported a follow-up study which indicated I6 per cent functional ambulators, 26 per cent usage for exercise or standing and 58 per cent non-usage of the orthoses.

\section{Method}

A written document was developed by the authors to be used in the telephone survey. It was felt that a telephone survey would reach a greater number of former patients and be more accurate than a mail survey as was done previously (Hahn, 1970). The physical therapists who had some longevity at Craig Hospital were chosen to make the phone calls. Meetings were conducted to explain the document to assure consistency. Emphasis was placed on being persistent in questioning the patients so as to get the most reliable data possible. Those patients who were either already at Craig Hospital for a re-evaluation or who were scheduled to do so in the immediate future were surveyed at Craig.

\section{Results}

Table I shows usage of the orthoses according to neurological groups: C8-T5 (no abdominals), T6-T9 (upper abdominals), Tro-LI (all abdominals). As we use the term, usage excludes those who only wear the braces while sitting or who use them for standing purposes only.

The average duration from the date braced to the date of follow-up was 45 months; the range being 6 months to I2 years. In Phase I, the average usage was 40 months, with a range of 3 months to 12 years. In Phase II, the average usage was 25 months, the range being 6 months to four years. There were I9I

TABLE I

Usage of Scott-Craig Orthosis

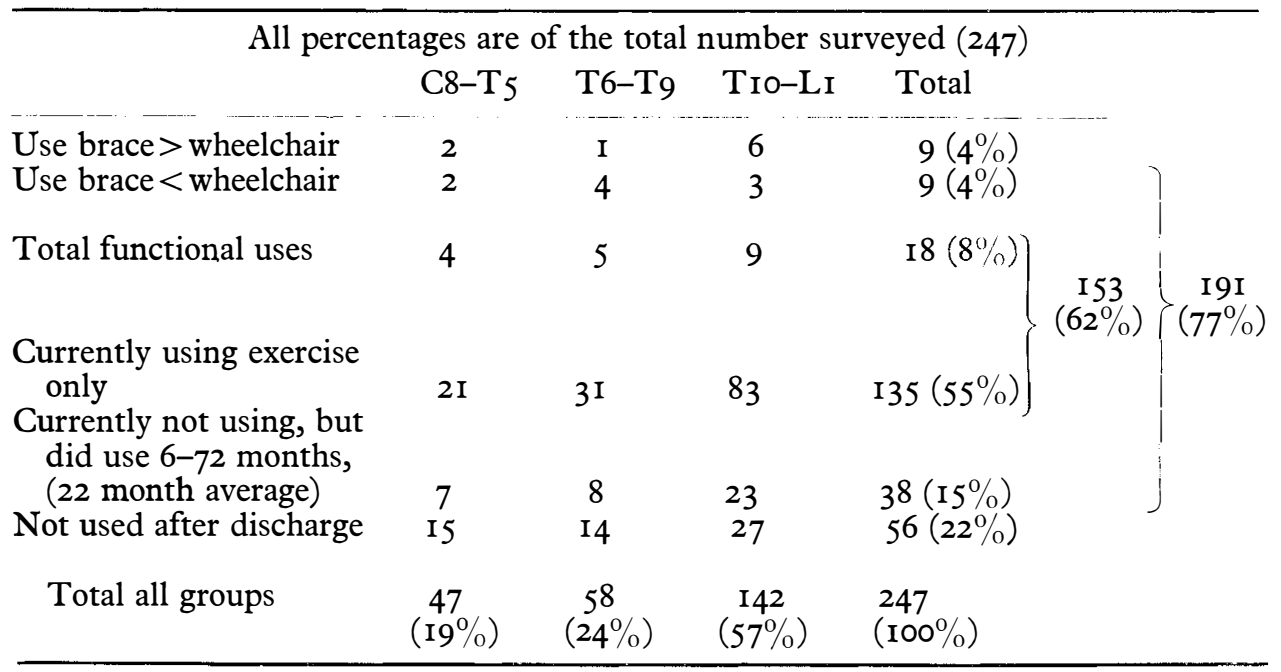


paraplegics ( 77 per cent of the 247 surveyed) who were using or had used their orthosis. One hundred and fifty-three ( 62 per cent) were currently using the orthosis. Of the I9I patients, 38 (I 5 per cent) had used their orthoses for a time, the range being 6 months to 6 years with an average of 22 months. Fifty-six patients ( 22 per cent) had not used their orthoses since discharge. We feel the data indicate a strong trend toward long-term usage of the Scott-Craig Orthosis for this group of paraplegics.

Eighteen ( 7 per cent of the total surveyed) were using the braces on a functional level. Functional level for the purpose of this study is defined as being able to use the braces in most normally encountered situations whenever they so desired. Included in this definition would be the ability to go up and down stairs, ambulate on uneven terrain, fall and get back to standing independently, and regular usage of the braces. The question was asked of this group as to whether they used the braces more or less than the wheelchair. Nine stated they used the braces more than the wheelchair, nine used them less than the wheelchair. Four functional users had no abdominal muscles, and five had upper abdominals only. (Refer to Table I.) This points out that in spite of the neurological level, with the brace design (i.e. the fixed ankle and the establishment of a point of balance) motivation on the part of the patient is a strong factor.

As we expected, 70 per cent or I 73 of the total surveyed use(d) the braces for exercise. Exercise is defined for this study as meaning using parallel bars or some type of houshold ambulation with crutches (or a walker) for short distances only. Usage varied from I-3 hours per day to a minimum of $\mathrm{I}$ hour a week.

The question was asked, 'Do you feel that using leg braces for exercise is important in spinal cord injuries?' Of the total surveyed, 215 (87 per cent) answered yes; I9 (8 per cent) answered no; I3 (5 per cent) were undecided. Another question was, 'If you had to do it over again, would you like to be braced?' From those currently using, or who had used the orthoses, I 76 said yes, I 5 said no. Thirty-nine of the non-users said yes, I6 said no. In summary, 215 (87 per cent) answered yes; 3 I (I3 per cent) no, and one did not answer. As a matter of interest, of those 94 patients not currently using the braces, 52 answered yes to the question regarding being braced again. It appears to the authors that most paraplegics who have had the chance at Craig Hospital to be braced felt this choice was important as an alternative to the wheelchair.

Most frequent reasons given to the above questions answered in the affirmative were: to stand, to exercise, to work (mobility), general health, to look people eye to eye (to see how tall a girl is!), to have the chance to try, and to get out of a wheelchair. Those who answered negatively most frequently said: neurological level too high, too much effort required, not necessary (nothing accomplished), waste of time and money, too old, prefer stall bars, pain and/or spasticity, and too lazy.

All those surveyed answered the question 'Do you find the braces difficult to put on and take off?' Seventy-three per cent answered no. Of the 27 per cent who answered yes, there were the following categories:

(a) difficult due to spasticity-I7 (6 per cent)

(b) difficult due to swelling of the feet-3 (I per cent)

(c) simply found it difficult-45 (I8 per cent).

The majority of patients (84 per cent) put on their braces in Io minutes or less. This speaks well for the unique design of the Scott-Craig Orthosis.

In answer to the question regarding the patient's interpretation of the emphasis 
on bracing by Craig personnel, I7 (7 per cent) said it was too much, 2I (9 per cent) said it was too little, 204 ( 83 per cent) said it was about right, and five ( 2 per cent) couldn't remember. A video tape detailing the pros and cons of brace ambulation is shown to the patients. If anything, bracing is presented in a straightforward, factual manner, emphasising the high energy expenditure. Discussions are held by the physicians and physical therapists with the patients. Usually a trial period using Scott-Craig Orthoses, available in the Physical Therapy Department, is encouraged, i.e., the patients have the option of whether or not to receive the orthoses. As we cannot cure in the traditional sense of the word, we feel that it is important in all aspects of the rehabilitation programme to teach the patient what is available. Then they can choose what best suits their life style.

The last question asked was open to subjective interpretation: 'Are the braces psychologically beneficial to you?' Even those not currently using the orthoses or who never used them to any significant degree, answered this question. No attempt was made to define 'psychologically beneficial' to the patients. We simply asked for a 'gut-level' response as to their own interpretation of its meaning. As can be seen in Table II, 73 per cent answered yes, 22 per cent no, and 5 per cent had no comment.

\section{TABLE II}

Are the braces psychologically beneficial to you?

\begin{tabular}{lrcc} 
& Used & Not used & Total \\
\cline { 3 - 4 } Yes & I45 & 35 & I80 $(73 \%)$ \\
No & 36 & I8 & $54(22 \%)$ \\
No comment & II & 2 & I3 $(5 \%)$ \\
$\quad$ Total & I92 & 55 & $247(100 \%)$ \\
\hline
\end{tabular}

\section{Discussion}

As stated previously, the intent of this survey was to define long-term usage of the Scott-Craig Orthoses for individuals with $\mathrm{L}_{\mathrm{I}}$ or above complete paraplegia. The authors had felt the majority of patients in the neurological grouping would be using the orthosis for exercise (household ambulation), if at all. The results of the survey, even realising that telephone surveys do have limitations, seem to indicate to us that a high percentage ( 77 per cen $t$ ) of our patients have used the braces sufficiently to justify bracing paraplegics.

The 83 per cent who felt the emphasis on bracing at Craig Hospital was just about right indicates to us that our approach, as far as the patient is concerned, is adequate. Eighty-seven per cent of those surveyed felt that using orthoses for exercise was important in SCI; 87 per cent said they would like to be braced if they had to do it over again; 73 per cent felt the braces had a psychological benefit.

These percentages indicate to the authors that bracing individuals with $\mathrm{L}_{\mathrm{I}}$ or above complete paraplegia with the Scott-Craig Orthosis has definite merits, both in the realm of physical long-term usage and in psychological benefits.

Acknowledgments. To the Physical Therapy staff members who assisted in the phone survey; to Florence Entrikin for the many times she typed the manuscript; to Kay Harris who so willingly typed the final draft on short notice. 


\section{SUMMARY}

A survey of the usage of the Scoț-Craig Orthosis among individuals with $\mathrm{LI}_{\mathrm{I}}$ or above complete motor and sensory paraplegia is reported. Patients were grouped according to those without volitionally controlled abdominal musculature (C8-T 5), those with volitionally controlled upper abdominal musculature (T6-T9), and those with all abdominal musculature under volitional control (Tro-Li). The study was done in two phases. Phase I, done in 1976, consisted of a survey of I84 patients in this neurological grouping who received the Scott-Craig Orthosis at Craig Hospital from I January I964 through to 3I December 1975. Phase II was completed in December 1980. Sixty-three additional patients were surveyed who were braced from I January 1976 through to 3I December I979. Seventy per cent of the total surveyed use(d) the orthosis for exercise ambulation. An additional seven per cent used the orthosis in a functional manner. Due to the patients' responses, the authors felt that in the realm of physical long-term usage and in psychological benefits, the bracing of LI or above paraplegics with the Scott-Craig Orthosis has definite benefits.

\section{RÉSUMÉ}

Une étude a été faite pour l'usage de Scott-Craig Orthosis parmi les individuels présentant une lésion complète de $\mathrm{C} 8$ à LI.

On a fait trois groups: $\mathrm{C} 8$ à $\mathrm{T}_{5}$ (sans muscles abdominaux)

T6 à T9 (avec en partie des muscles abdominaux)

Tio à Li (avec la totalité des muscles abdominaux).

Cette étude a été faite en deux phases. La première phase, faite en 1976, était composés d'une étude de I 84 paraplégiques quui ont reçu leurs orthoses à l'hôpital Craig entre le I $^{\mathrm{er}}$ Janvier 1964 et le 3 I Decembre 1975. La $2^{\mathrm{eme}}$ phase, terminée en Décembre I980, comprenait 63 paraplégiques de plus. Ces derniers recevraient leurs orthoses entre le $\mathrm{I}^{\mathrm{er}}$ Janvier I976 et le 3 I Décembre I979.

Cette étude a démontre que $70 \%$ utilisaient leurs orthoses normalement pour exercices, alors que $7 \%$ autres utilisaient leurs orthoses pour fonctions régulières. Le résultat de l'étude démontre aux auteurs que l'usage prolongés des orthoses pourvoie des bénéfices physiques et psychologiques pour ce groupe neurologique.

\section{ZUSAMMENFASSUNG}

Eine Übersicht des Gebrauchs der 'Scott-Craig Orthosis' von Betroffenen mit motorisch und sensitel kompletten Läsionen von LI oder darüber wird berichtet. Die Patienten wurden entsprechend der Läsionshohe eingestuft ohne bewußte Bauchmuskulaturkontrolle $\left(\mathrm{C}_{8}-\mathrm{T}_{5}\right)$, solche mit oberen Bauchmuskeln mit Bewußtseinskontrolle (T6-T9) und solche mit allen Bauchmuskeln mit Bewußtseinskontrolle (Tro-LI). Der Test wurde in zwei Teilen erarbeitet. Phase I, erarbeitet in 1976, bestand aus einer Úbersicht von I84 Patienten in dieser neurologischen Gruppe, welche die 'Scott-Craig Orthosis' im Craig Spital vom I. Januar 1964 bis 31. Dezember 1975 erhielten. Phase II wurde im Dezember 1980 beendet. Weitere 63 Patienten wurden überprüft, die Gehapparate benützten vom I. Januar 1976 bis 31. Dezember I979. Siebzig prozent, von denen überprüft, benützten die Gehapparate für regelmässige körpliche Training während die weitere $7 \%$ gingen mit den Gehapparaten in einer function $\in$ llen Art. Es wurde in dieser neurologischen Gruppe festgestellt, daß die Langzeitbenützung der 'Scott-Craig Orthosis' körpliche und psychologische Vorteilen hat. 


\section{REFERENCES}

Coghlan, J. K., Robinson, C. E., Newmarch, B. \& Jackson, B. (I980). Lower extremity bracing in paraplegia-a follow-up study. Paraplegia, 18, 25-32.

HAHN, H. R. (1970). Lower extremity bracing in paraplegics with usage follow-up. Paraplegia, 8, I 47-I 53.

Rosman, N., SpIRA, E. (I974). Paraplegic use of walking braces: a survey. Arch. Phys. Med. Rehabil. 55, 310-314.

STAUFFER, E. S., HOFFER, M. M. \& Nickel, V. L. (1978). Ambulation in thoracic paraplegia. F. Bone foint Surg. (AM), 60-A, 823-824. 